\author{
면역거세가 수퇘지의 생리적 변화, 도체 및 육질 특성의 차이에 \\ 미치는 영향 \\ 김영화 · 정현정 · 이성대 · 지상윤 · 박준철 · 문홍길 \\ 농촌진흥청 축산과학원
}

\title{
Effects of Immunocastration on Physiological Changes, the Characteristics of Carcass and Meat Quality in Boars
}

\author{
Y. H. Kim, H. J. Jung, S. D. Lee, S. Y. Ji, J. C. Park and H. K. Moon \\ National Institute of Animal Science, RDA, Cheonan 330-801, Korea
}

\begin{abstract}
This study was undertaken to investigate the effects of the immunocastration on the growth performance, the characteristics of carcass and meat quality in boar. Total 45 piglets (Landrace $\times$ Yorkshire) were prepared from the birth and were fed the experimental diet by the time to be slaughtered at around 110 $\mathrm{kg}$ of body weight. The experimental groups consisted of five piglets per pen with 3 replicates in three treatment groups, non castrated (NC), surgically castrated (SC), and GnRH antagonist (GA).

In SC group, all piglets aged 3-4 days after birth were castrated by the surgical method. For the immunocastration, $2 \mathrm{ml}$ of $\mathrm{GnRH}$ antagonist (Improvac, Pfizer, Australia) were subcutaneously injected into piglets twice on the 16th and 20th week after the beginning of the trial in the GA group.

The immunocastration did not make any significant influences on the growth performance, as compared with the other treatments. The different castration method used in either GA or SC group pigs had similar effects on the dressing percentage and body fat content as carcass parameters. In respect of a meat quality, the meat color, $\mathrm{pH}$, shearing force and cooking loss were not significantly different in all treatment groups. Testosterone concentration in serum was shown to be similar between GA and SC group at 2 weeks after the 2nd injection of GnRH antagonist. The weight of bulbourethral gland and the radius and weight of testis were significantly smaller in GA than in $\mathrm{NC}(\mathrm{P}=0.002)$.

All together, this study suggested that the castration by immunocastration can be an alternative method for the surgical castration without any changes in growth performance, the characteristics of carcass and meat quality shown in surgical castration group.
\end{abstract}

(Key words : Boar, Growth performance, Immunocastration, Carcass characteristics, Testosterone)

$$
\text { I. 서 론 }
$$

웅취는 수퇘지의 지방 및 살코기에 웅취 유 발 성분인 androsterone과 skatol이 축적되어 풍
기는 독특하고 불쾌한 냄새를 말한다(Beery 등, 1971; Thompson 등, 1972). 스테로이드 호르몬 의 일종인 androsterone 및 트립토판의 대사체인 skatol 성분이 웅취의 원인물질로 보고되었다

Corresponding author :S. D. Lee, Swine Research Division, National Institute of Animal Science, Cheonan 330-801, Korea, Phone: 041)580-3452, e-mail: sungdae@rda.go.kr 
(Thompson 등, 1972). 돈육의 웅취를 제거하기 위해서 거세를 실시하고 있으며, 어린 자돈의 거세는 스트레스를 유발하여 성장을 저해하고 동물복지차원에서 문제가 제기되고 있다.

양돈농가는 일반적으로 수퇘지의 거세는 생 후 3일령에서 7일령 사이에 실시하고 있고 (Beery 등, 1971; Booth 등, 1986; Brooks와 Pearson, 1986), 신생자돈의 거세는 성장 지연, 도체 품질 저하를 일으켜 경제적 손실을 초래 하는 것으로 보고되었다(Newell과 Bowland, 1972; Walstra, 1974).

최근에 면역생물학 제제를 투여하여 수퇘지 의 거세 효과에 대한 많은 연구가 진행되고 있

다(Bonneau 등, 1994; Meloen 등, 1994; Cronin 등, 2003). 면역생물학 제제의 거세효과는 성선 자극호르몬 분비 호르몬 $(\mathrm{GnRH})$ 의 작용을 저해 시켜 혈중 황체호르몬(LH) 및 난포자극호르몬 (FSH) 분비를 억제하므로써 testosterone의 분비 와 작용을 억제하여 정소 및 부생식선의 기능 을 퇴화시켜 웅취를 감소시킨다(Oonk 등, 1998; Oonk 등, 1995). $\mathrm{GnRH}$ 의 작용에 의해 $\mathrm{LH}$ 와 $\mathrm{FSH}$ 는 정소내의 간질세포에 작용하여 testosterone 의 분비를 촉진하고 testosterone의 작용에 의해 정자 형성 및 부생식선의 활성을 조절한다 (Schnare와 Fischer, 1987). 이러한 면역생물학 제제의 $\mathrm{GnRH}$ 의 기능 저해 작용에 의해 웅취 성분 (androsterone 및 Skatol)의 분비와 축적을 감소시켜 육질이 개선되고, 정소기능의 퇴화에
따른 수퇘지 행동을 순화시키므로 생산성 개선 효과가 있는 것으로 보고되고 있다(Jaros 등, 2005; Meloen 등, 1994; Cronin 등, 2003).

현재 국내에서 면역생물학 제제를 이용한 수 퇘지의 거세효과에 대한 연구는 보고되고 있지 않다. 따라서 본 연구에서는 수퇘지에서 면역 생물학 제제 투여에 따른 돼지 생산성, testosterone 함량, 도체 및 육질 특성에 미치는 영 향을 조사하여 거세효과를 구명하고자 수행하 였다.

\section{․ 재료 및 방법}

\section{1. 사양 시험}

공시동물은 2원교잡종 $(\mathrm{L} \times \mathrm{Y})$ 21일령 자돈 45 두를 공시하였고, 시험장소는 축산과학원 양돈 과 사양시험돈사에서 출하체중 $110 \mathrm{~kg}$ 도달 때 까지 실시하였다. 시험구 배치는 비거세구(NC), 거세구(SC), 면역생물학 제제 투여구(GA)로 나 누어 돈방당 5 두씩 완전임의 배치하여 3 회 반 복하였다. 거세는 생후 3-4일령의 자돈에서 외 과적 방법으로 실시하였다. 면역생물학 제제 투 여는 GnRH antagonist(Improvac, Pfizer, Australia) 를 시험개시 후 16 주와 20 주에 각각 두당 $2 \mathrm{ml}$ 씩 2회에 걸쳐 피하주사하였다. 시험사료의 화 학적 조성은 사육단계별로 영양수준을 조정하 여 급여하였다(Table 1). 사료급여는 무제한 급

Table 1. The chemical composition of experimental diets

\begin{tabular}{lccccc}
\hline \multirow{2}{*}{ Item } & \multicolumn{5}{c}{ Feeding period (weeks) } \\
\cline { 2 - 6 } & $0 \sim 4$ & $4 \sim 7$ & $7 \sim 11$ & $11 \sim 15$ & $15 \sim 23$ \\
\hline \hline DE, kcal/(kg ${ }^{1)}$ & - & 3,600 & 3,550 & 3,500 & 3,500 \\
C. Protein & 21.6 & 19.2 & 19.8 & 17.6 & 16.9 \\
C. Fat & 9.1 & 7.2 & 6.2 & 8.1 & 7.9 \\
C. Fiber & 2.2 & 4.2 & 3.6 & 4.3 & 4.1 \\
C. Ash & 6.2 & 5.5 & 5.3 & 4.9 & 4.2 \\
Ca & 0.58 & 1.20 & 0.75 & 0.79 & 0.61 \\
Lysine & 1.81 & 1.32 & 1.29 & 1.17 & 1.14 \\
Cystine & 0.41 & 0.32 & 0.28 & 0.27 & 0.26 \\
Methionine & 0.35 & 0.27 & 0.23 & 0.21 & 0.20 \\
\hline
\end{tabular}

1) $\mathrm{DE}$ was calculated from ingredient proportion 
여, 음수는 자유급수를 실시하였다. 시험돈사는 무창돈사이며 돈방 면적은 $320 \times 150 \mathrm{~cm}$ 이다.

체중은 $0,3,7,10,14,16,18,22,25$ 주로 8 회 측정하였다. 일당 증체량은 총 증체량에서 사육일수를 나누어 계산하였고, 일당 사료섭취 량은 총 사료섭취량에서 사육일수를 나누어 계 산하였다. 사료요구율은 사료섭취량에서 증체 량을 나누어 계산하였다.

\section{2. 도체 및 육질 분석}

공시동물은 종료체중을 조사한 후 도축장에 서 12시간 절식한 후 도축하였다. 도체는 도체 냉각실 $\left(2 \pm 2^{\circ} \mathrm{C}\right)$ 에서 24 시간 냉각하였다. 지육율 (Dressing, \%)은 지육중량을 도체중량으로 나누 어 계산하였다. 등심단면적(Longissimus dosi area, $\mathrm{cm}^{2}$ ), 등지방 두께(Back-fat thickness, cm), 상강 도(Marbling score) 및 도체등급(Carcass grade)은 농림부고시 제 2004-10호의 축산물등급판정세 부기준에 따라 등급판정사가 판정하였고, 도체 등급의 $\mathrm{A}, \mathrm{B}, \mathrm{C}, \mathrm{D}$ 를 $1,2,3,4$ 로 각각 계수화 하여 나타내었다.

육질분석은 도축 후 24시간 예냉한 도체에서 공시재료로 배최장근(Longissimus dorsi muscle) 을 정형한 후에 채취하였으며, 랩으로 포장하 여 $0 \pm 1^{\circ} \mathrm{C}$ 에서 24 시간 저장한 후 육질 분석을 위한 공시재료로 이용하였다. 육색은 등심근 단면을 자른 후 $4^{\circ} \mathrm{C}$ 에서 30 분간 발색시킨 후 색차계(CR-300, Minolta, Japan)를 이용하여 동 일한 시료를 3회 반복하여 측정하였다. 표준화 작업은 표준색판 No. 12633117을 이용하여 $\mathrm{Y}=$ 93.5, $\mathrm{x}=0.3136, \mathrm{y}=0.3198$ 값으로 표준화시킨 후 육색을 측정하였다. $\mathrm{pH}$ 는 도축 24시간 후 좌 도체 등심 제 10 늑골부위에서 $\mathrm{pH}$ meter (NWKbinar pH K-21, Germany)를 이용하여 측 정하였다. 전단력 (Shear force value, $\mathrm{kg}$ )은 가열 한 시료를 직경 $1.27 \mathrm{~cm}^{2}$ 의 코아로 시료를 근 섬유 방향으로 채취한 후 전단력 측정기 (Warner-Bratzler Shear Meter, USA)로 측정하였 다. 가열감량(Cooking loss, \%)은 시료를 $2 \mathrm{~cm}$ 두께로 일정하게 절단하여 무게를 측정하고 70 ${ }^{\circ} \mathrm{C}$ 항온수조에서 10 분간 가열한 다음 냉각시켜
감량된 무게를 백분율로 산출하였다. 보수력 (WHC, \%)은 마쇄한 시료 $10 \mathrm{~g}$ 을 $70^{\circ} \mathrm{C}$ 의 항온수 조에서 30 분간 가열한 다음 방냉하여 $1,000 \mathrm{rpm}$ 에서 10 분간 원심분리한 후 유리수분 함량을 측정하고, 동일한 시료 $10 \mathrm{~g}$ 을 dish에 담아서 $102 \pm 1{ }^{\circ} \mathrm{C}$ dry oven에서 건조시켜 전수분 함량 을 측정하여 계산하였다. 조지방(Crude fat, \%) 은 AOAC(1995) 방법에 준하여 Soxhlet 법을 이 용하여 분석하였다.

\section{3. 혈중 testosterone 분석 및 생식기 측정}

혈액 채취는 면역생물학 제제 1 차 투여 전, 2차 투여 전 그리고 2차 투여 후 2주 후에 경 정맥에서 채혈하였고, 혈액은 $1,500 \times \mathrm{g}$ 에서 10 분 간 원심분리하여 혈청을 분리하였다. 분리된 혈청은 분석 전까지 $-80^{\circ} \mathrm{C}$ 에서 보관하였다. Testosterone 분석은 Coat-A-Count Testosterone Kit(DPC, USA)를 이용하여 y-Counter(Cobra 5010 Quantum, Packard, USA)로 분석하였다. 도축 시 에 생식기를 적출하여 정소직경, 무게 및 요도 구선 무게를 각각 측정하였다.

\section{4. 통계 분석}

생산성, testosterone 함량, 도체 및 육질에서 얻어진 결과는 SAS(1999)의 GLM(General Linear Model)을 이용하여 Duncan의 Multiple Range Test로 유의성을 검정하였다. 생식기 크기 및 무게를 측정한 결과는 t-test를 이용하여 분석하 였다.

\section{III. 결과 및 고찰}

면역생물학 제제 투여에 따른 생산성을 조사 한 결과는 Table 2에 나타낸 바와 같이 일당증 체량은 각 처리구 간에 유의적인 차이는 나타 나지 않았다. 사료섭취량은 처리 간에 유의적 인 차이는 없었지만, NC보다 SC 및 GA에서 다소 높은 경향을 보였고, 사료요구율은 SC가 $\mathrm{NC}$ 보다 유의적으로 높았다 $(\mathrm{P}<0.05)$. 이러한 결 과는 육성기의 돼지에서 외과적인 방법과 면역 
Table 2. The effect of the castration method on the growth performance ${ }^{1)}$

\begin{tabular}{lcccl}
\hline \multicolumn{1}{c}{ Item } & $\mathrm{NC}$ & $\mathrm{SC}$ & $\mathrm{GA}$ & $\mathrm{SE}$ \\
\hline \hline Initial weight, kg & 4.7 & 5.0 & 4.7 & 0.32 \\
Final weight, kg & 117.3 & 115.8 & 118.7 & 3.88 \\
ADG, kg/day & 0.71 & 0.70 & 0.72 & 0.026 \\
ADFI, kg/day & 1.88 & 1.98 & 2.00 & 0.072 \\
Feed/Gain & $2.68^{\mathrm{b}}$ & $2.85^{\mathrm{a}}$ & $2.80^{\mathrm{ab}}$ & 0.042 \\
\hline
\end{tabular}

1) NC, Non castrates; SC, Surgically castrated; GA, GnRH antagonist

${ }^{\mathrm{a}, \mathrm{b}}$ Means in the same row with different superscripts significantly differ $(\mathrm{P}<0.05)$

생물학 제제를 이용한 거세효과를 구명하기 위 하여 생산성을 조사한 결과 증체량에는 영향을 주지 않았으나, 사료섭취량은 외과적 거세가 면역생물학적 거세보다 줄었다고 보고한 결과 (Cronin 등, 2003)와 유사한 경향을 나타내었 고, 면역생물학 제제 투여로 외과적 거세 효과 를 나타내는 것을 확인할 수 있었다.

면역생물학 제제 투여에 따른 정소기능 저하 가 돼지 도체특성에 미치는 영향을 조사한 결 과는 Table 3에 나타낸 바와 같다. 도체 중량을 조사한 결과는 처리 간에 유의적인 차이는 없 는 것으로 조사 되었으며, $\mathrm{SC}$ 와 $\mathrm{GA}$ 가 $\mathrm{NC}$ 보다 다소 높은 경향을 나타내었고, 정육율은 $\mathrm{SC}$ 와 $\mathrm{GA}$ 가 $\mathrm{NC}$ 보다 유의적으로 높은 것으로 조사 되었다 $(\mathrm{P}<0.05)$. 지육중량 및 지육율은 처리 간 에 유의적인 차이를 나타내지 않았으며, SC보 다 GA가 다소 높은 경향을 나타내었다. 등지방
두께는 SC와 GA가 $\mathrm{NC}$ 보다 높은 경향을 보였 으나 처리 간에 유의적인 차이는 나타나지 않 았다. 체지방 함량을 조사한 결과 $\mathrm{NC}$ 보다 $\mathrm{SC}$ 와 $\mathrm{GA}$ 가 유의적으로 높게 나타났다 $(\mathrm{P}<0.05)$. 도체등급은 $\mathrm{SC}$ 가 $\mathrm{NC}$ 및 $\mathrm{GA}$ 보다 유의적으로 높은 등급을 받은 것으로 조사 되었다 $(\mathrm{P}<0.05)$. Jaros 등(2006)은 GnRH antagonist를 투여에 따 른 거세효과 구명연구에서 $\mathrm{GnRH}$ antagonist 투 여는 지육율을 개선하는 것으로 보고하였다. 수퇘지에서 $\mathrm{GnRH}$ antagonist 투여는 투여하지 않은 수퇘지에 비해 등지방두께가 증가된다고 보고하였다(Falvo 등, 1986; Hagen 등, 1988). 본 시험에서 등지방두께는 SC와 GA가 $\mathrm{NC}$ 보다 높 은 경향을 나타낸 것과 체지방 함량이 NC보다 $\mathrm{SC}$ 와 GA가 유의적으로 높게 나타난 결과와 유 사한 경향이었으며, 면역생물학 제제를 투여하 는 것은 외과적 거세와 유사한 효과를 나타내

Table 3. The effect of the castration method on the carcass parameters ${ }^{1)}$

\begin{tabular}{lcccc}
\hline \multicolumn{1}{c}{ Item } & NC & SC & GA & SE \\
\hline \hline Carcass weight, kg & 81.2 & 82.8 & 83.7 & 3.01 \\
Dressing percent, \% & $72.5^{\mathrm{b}}$ & $75.0^{\mathrm{a}}$ & $73.9^{\mathrm{a}}$ & 0.39 \\
Lean meat weight, kg & 54.6 & 53.6 & 54.9 & 1.861 \\
Lean meat percent, \% & 66.7 & 64.9 & 66.6 & 1.473 \\
Back-fat thickness, mm & 1.66 & 2.19 & 2.22 & 0.201 \\
Body Fat, kg & $4.39^{\mathrm{b}}$ & $5.91^{\mathrm{a}}$ & $5.91^{\mathrm{a}}$ & 0.427 \\
Carcass Grade & $3.92^{\mathrm{a}}$ & $2.31^{\mathrm{b}}$ & $3.92^{\mathrm{a}}$ & 0.167 \\
\hline
\end{tabular}

1) NC, Non castrates; SC, Surgically castrated; GA, GnRH antagonist

a, b Means in the same row with different superscripts significantly differ $(\mathrm{P}<0.05)$ 
는 것을 확인 할 수 있었다.

면역생물학 제제 투여가 육질에 미치는 영향 을 조사한 결과는 Table 4에서 보는 바와 같다. 육색에서 $\mathrm{CIE} \mathrm{L}^{*}, \mathrm{a}^{*}, \mathrm{~b}^{*}$ 와 $\mathrm{pH}$ 는 처리 간에 유 의적인 차이가 나타지 않았으나, $\mathrm{CIE} \mathrm{L}^{*}, \mathrm{a}^{*}$, $\mathrm{b}$ *는 $\mathrm{NC}$ 보다 SC와 $\mathrm{GA}$ 가 낮은 경향을 보였고 $\mathrm{pH}$ 는 $\mathrm{NC}$ 보다 $\mathrm{SC}$ 와 $\mathrm{GA}$ 에서 높은 경향을 나타 내었다. 전단력 및 가열감량은 처리 간에 유의 적인 차이를 나타내지 않았지만, $\mathrm{NC}$ 가 $\mathrm{SC}$ 와 $\mathrm{GA}$ 보다 전단력과 가열감량이 높은 것으로 나 타났다. 보수력 및 조지방 함량에서도 처리 간 에 유의적인 차이를 나타내지 않았지만, GA가 다른 처리에 비하여 다소 높은 경향을 나타내 었다. Hennessy 등(2000)은 GnRH antagonist 투 여에 따른 육질 특성을 조사한 결과 수퇘지에
비하여 근내 지방 함량과 육즙 삼출이 개선된 다고 보고하였다. 이는 외과적 거세 효과를 $\mathrm{GnRH}$ antagonist 투여가 외과적 거세 효과를 나타낸 것으로 사료된다.

면역생물학 제제 투여에 따른 혈중 testosterone 농도를 조사한 결과는 Table 5에 나타 낸 것과 같다. 면역생물학 제제 1 차 투여 전과 2차 투여 전 혈중 testosterone 농도를 조사한 결과 $\mathrm{SC}$ 보다 $\mathrm{NC}$ 와 $\mathrm{GA}$ 가 유의적으로 높게 나 타났다 $(\mathrm{P}<0.05)$. 면역생물학 제제 2차 투여 2주 후 혈중 testosterone 농도는 GA가 SC와 유사한 농도로 감소하였으며, $\mathrm{NC}$ 보다 $\mathrm{SC}$ 와 $\mathrm{GA}$ 이 유 의적으로 낮게 나타났다 $(\mathrm{P}<0.05)$. 면역생물학 제제 2차 투여 전의 혈중 testosterone 농도의 변화가 나타나지 않은 것은 면역체계만 자극하

Table 4. The effect of the castration method on the meat quality ${ }^{1)}$

\begin{tabular}{lrrrr}
\hline Item & NC & SC & GA & SE \\
\hline \hline Meat color & & & \\
CIE L* & & & 51.46 & 0.647 \\
CIE a* $^{2)}$ & 52.14 & 51.90 & 7.31 & 0.395 \\
CIE b* & 7.93 & 7.32 & 3.67 & 0.287 \\
pH & 4.13 & 4.03 & 5.63 & 0.017 \\
Shearing value, kg & 5.59 & 5.62 & 12.32 & 3.174 \\
Cooking loss, \% & 15.52 & 13.32 & 30.75 & 0.610 \\
WHC, \% & 32.52 & 31.88 & 58.50 & 0.704 \\
Crude Fat, \% & 57.39 & 56.32 & 1.57 & 0.185 \\
\hline
\end{tabular}

1) NC, Non castrates; SC, Surgically castrated; GA, GnRH antagonist

${ }^{2)} \mathrm{CIE} \mathrm{L*}$, Black (0) to white (100) color scale; CIE a*, red (+) to green $(-)$ color scale; CIE b*, yellow $\left(^{+}\right)$ to blue (-) color scale

3) WHC, Water holding capacity.

Table 5. The change of serum testosterone concentration $(\mathrm{ng} / \mathrm{ml})$ by the castration method ${ }^{1)}$

\begin{tabular}{lllll}
\hline \multicolumn{1}{c}{ Item } & NC & SC & GA & SE \\
\hline \hline Before the first injection & $1.17^{\mathrm{a}}$ & $0.10^{\mathrm{b}}$ & $1.39^{\mathrm{a}}$ & 0.267 \\
Before the second injection & $1.65^{\mathrm{a}}$ & $0.14^{\mathrm{b}}$ & $1.55^{\mathrm{a}}$ & 0.279 \\
2 week after the second injection & $3.63^{\mathrm{a}}$ & $0.26^{\mathrm{b}}$ & $0.49^{\mathrm{b}}$ & 0.847 \\
\hline
\end{tabular}

1) NC, Non castrates; SC, Surgically castrated; GA, GnRH antagonist

a, b Means in the same row with different superscripts significantly differ $(\mathrm{P}<0.05)$ 
Table 6 . The changes of testis and bulbourethral gland by the castration method ${ }^{1)}$

\begin{tabular}{lccccc}
\hline Item & NC & SC & GA & SE & P-value \\
\hline \hline Testis weight, g & 317.4 & - & 168.2 & 20.48 & 0.006 \\
Testis widths, mm & 76.9 & - & 60.3 & 2.18 & 0.002 \\
Bulbourethral gland, g & 57.7 & - & 36.9 & 4.56 & 0.002 \\
\hline
\end{tabular}

1) NC, Non castrates; SC, Surgically castrated; GA, GnRH antagonist

였기 때문으로 사료된다.

생식기 무게 및 크기 변화는 Table 6에 나타내 었다. 정소와 요도구선 무게는 $\mathrm{GA}$ 가 $\mathrm{NC}$ 보다 유의적으로 작았고 $(\mathrm{P}=0.006)$, 정소 직경도 $\mathrm{GA}$ 가 $\mathrm{NC}$ 보다 유의적으로 작았다 $(\mathrm{P}=0.002) . \mathrm{GnRH}$ antagonist는 $\mathrm{GnRH}$ 의 작용을 억제하여 혈중 $\mathrm{LH}$ 및 FSH 분비를 감소시키고, 이로 인해 정소 내 의 간질세포에서 분비되는 testosterone이 급격 히 감소되며(Oonk 등, 1998, Oonk 등, 1995), testosterone 농도의 저하로 인해 정소 및 부생 식선의 기능이 저하되고 정소 직경 및 무게가 줄었다고 하였다(Turkstra 등, 2002; Meloen 등, 1994; Dunshea 등, 2001). GnRH antagonist 투여 는 무처리에 비해 혈중 testosterone 농도를 감 소시켜 외과적 거세 돼지와 비슷한 수준의 농 도를 나타낸다고 한 결과는 (Meloen 등, 1994; Dunshea 등, 2001) 본 시험에서 혈중 testosterone 농도 및 생식기 크기 변화와 유사한 결과를 나타내었다.

$$
\text { V. 요 약 }
$$

본 시험은 돼지에서 면역생물학 제제 투여에 따른 거세 효과를 구명하기 위해서 수행되었 다. 공시동물은 2원교잡종(Landrace×Yorkshire) 21일령 자돈 45 두를 공시하였고, 시험사육은 출하체중 $110 \mathrm{~kg}$ 도달 때까지 실시하였다. 시험 구 배치는 비거세구(NC), 거세구(SC), 면역생물 학 제제 투여구(GA)로 나누어 돈방당 5두씩 완 전임의 배치하여 3회 반복하였다. 거세는 생후 3-4일령의 자돈에서 외과적 방법으로 실시하였 다. 면역생물학 제제 투여는 $\mathrm{GnRH}$ antagonist (Improvac, Pfizer Australia)를 시험개시 후 16주
와 20 주에 각각 두당 $2 \mathrm{ml}$ 씩 2회에 걸쳐 피하주 사하였다.

면역생물학 제제 투여에 따른 생산성은 다른 처리구에 비해 유의적인 차이는 나타나지 않았 다. 도체특성에서, 정육율과 체지방 함량은 면 역생물학 제제 투여에 의해 외과적 거세와 유 사한 효과를 나타내었다. 육질 특성에서, 육색, $\mathrm{pH}$, 전단력 및 가열 감량은 유의적인 차이를 나타내지 않았다. 혈중 testosterone 농도는 면역 생물학 제제 2차 투여 2주 후에 일반 거세와 유사한 경향을 보였다. 생식기에서 정소 직경, 무게 및 요도구선 무게는 면역생물학 제제 투 여에 의해서 비거세 돼지보다 유의적으로 작았 다 $(\mathrm{P}=0.002)$.

따라서 본 시험에 이용한 면역생물학 제제를 투여하였을 때 도체 및 육질에 있어서 일반 거 세와 비슷한 효과를 나타내었으므로 외과적 수 술에 의한 거세를 대처할 수 있을 것으로 사료 된다.

\section{$\mathrm{V}$. 인 용 문 헌}

1. Beery, K. E., Sink, J. D., Patton, S. and Ziegler, J. H. 1971. Characterization of the swine sex odor (SSO) components in boar fat volatiles. J. Food Sci. 36:1086-1090.

2. Bonneau, M., Dufour, R., Chouvet, C., Roulet, C., Meadus, W. and Squires, E. J. 1994. The effects of immunization against luteinizing hormonereleasing hormone on performance, sexual development, and levels of boar taint-related compounds in intact male pigs. J. Anim. Sci. 72:14-20.

3. Booth, W. D., Williamson, E. D. and Patterson, 
R. L. S. 1986. 16-Androstene steroids in the submaxillary salivary gland of the boar in relation to measures of boar taint in carcasses. Anim. Prod. 65:381-388.

4. Brooks, R. I. and Pearson, A. M. 1986. Steroid hormone pathways in the pig, with special emphasis on boar odor: a review. J. Anim. Sci. 62:632-645.

5. Cronin, G. M., Dunshea, F. R., Butler, K. L., McCauley, I., Barnett, J. L. and Hemsworth, P. H. 2003. The effects of immuno- and surgicalcastration on the behaviour and consequently growth of group-housed, male finisher pigs. App. Anim. Behav. Sci. 81:111-126.

6. Dunshea, F. R., Colantoni, C., Howard, K., McCauley, I., Jackson, P., Long, K. A., Lopaticki, S., Nugent, E. A., Simons, J. A., Walker, J. and Hennessy, D. P. 2001. Vaccination of boars with a GnRH vaccine (Improvac) eliminates boar taint and increases growth performance. J. Anim. Sci. 79:2542-2535.

7. Falvo, R. E., Chandrashekar, V., Arthur, R. D., Kuenstler, A. R., Hasson, T., Awoniyi, C. and Schanbacher, B. D. 1986. Effect of active immunization against LHRH or LH in boars: reproductive consequences and performance traits. J. Anim. Sci. 63:986-994.

8. Forland, D. M., Lundstrom, K. and Andresen, O. 1980. Relationship between androstenone in fat, intensity of boar taint and size of accessory sex glands in boars. Nord. Vaterinaermed. 32:201-206.

9. Hagen, G., Andresen, O., Framstad, T., Bliechfield, T. and Berg, K. A. 1988. Effects of immunization of young boars against gonadotropinreleasing hormone. Proc. XIth Cong. Anim. Reprod. A. I. Dublin. 493-495.

10. Hennessy, D. P., Dunshea, F. R., McCaauley, I., Colantoni, C., Jackson, P., Long, K. A., Lopaticki, S., Nugent, E. A., Simons, J. A. and Walker, J. 2000. Immunocastration-world first boar taint vaccine. Proceedings of the 16th International Pig Veterinary Society Congress, Melbourne, Australia. pp:315-323.

11. Jaros, P., Burgi, E., Stark, K. D. C., Claus, R., Hennessy, D. and Thun, R. 2005. Effect of active immunization against $\mathrm{GnRH}$ on androstenone concentration, growth performance and carcass quality in intact male pigs. Livest. Prod. Sci. 92:31-38.

12. Meloen, R. H., Turkstra, J. A., Lankhof, H., Puijk, W. C., Schaaper, W. M. M., Dijkstra, G., Wensing, C. J. G. and Oonk, R. B. 1994. Efficient immunocastration of male piglets by immunoneutralization of GnRH using a new GnRH-like peptide. Vaccine. 12:741-746.

13. Newell, J. A. and Bowland, J. P. 1972. Performance, carcass composition and fat composition of boars, gilts and barrows fed two levels of protein. Can. J. Anim. Sci. 52:543-551.

14. Oonk, H. B., Turkstra, J. A., Lankhof, H., Schaaper, W. M. M., Verheijden, J. H. M. and Meloen, R. H. 1995. Testis size after immunocastration as parameter for the absence of boar taint. Livest. Prod. Sci. 42:63-71.

15. Oonk, H. B., Turkstra, J. A., Schaaper, W. M. M., Eraens, J. H. F., Schuitemaker-de Weerd, M. H., van Nes, A., Verheijden, J. H. M. and Meloen, R. H. 1998. New GnRH-like peptide construct to optimize efficient immunocastration of male pigs by immunoneutralization of $\mathrm{GnRH}$. Vaccine. 16:1074-1082.

16. Schnare, H. and Fisher. K. 1987. Secondary sex characteristics and connected physiological values in male fallow deer (Dama dama) and their relationship to changes of the annual photoperiod : doubling the frequency. J. Exp. Zool. 244: 463-471.

17. Thompson Jr, R. H., Pearson, A. M. and Banks, K. A. 1972. identification of some of the C19- $\triangle$ 16 steroids contributing to sex odor in pork. J. Agr. Food Chem. 20:185-189.

18. Turkstra, J. A., Oonk, H. B., Schaaper, W. M. M. and Meloen, R. H. 2002. The role of the individual amino acids of a GnRH-tandem-dimer 
Kim et al. ; Immunocastration of Boars

peptide used as an antigen for immunocastration of male piglets determined with systematic alanine replacements. Vaccine. 20:406-412.

19. Walstra, P. 1974. Fattening of young boars: quanti- fication of negative and positive aspects. Livest.

Prod. Sci. 1:187-196.

(접수일자 : 2007. 8. 13. / 채택일자 : 2007. 12. 3.) 